loss of life. Therefore, for the two great countries of Europe it is rather a question of tiding over immediate difficulties.

It looks now as if the danger in the world and certainly in this country of radical controt of labor was over. The conservative element in labor will certainly carefully guard the interests. of the laboring classes, and their broad outlook and conservative action can be relicd upon to. pursue measures that will tend to the public good.

Philadelfmia, January 6, 1920.

[Signed] HARRY B. FRENCH.

\title{
EDITOR:
}

Mr. England's editorial on coöperation contains elements of hope, for it may be possible in this way to secure reforms beneficial to professional pharmacy and to the sick without entering into entangling alliances.

Lest I may be regarded as a pessimist, I have confidence in the desire of the average man to give the best that is in him; when the contrary obtains, it is due to the glimmer of a supermercenary goal obstructing a proper course.

In what direction is coöperation to be centered? Unless it results in a benefit to the ultimate consumer it may be regarded as a conspiracy. So, let us begin along fair lines, by asking the Association of Manufacturing Chemists to coöperate with us in serving the public well, by the discontinuance of marketing "reduced iron, black, 60 percent" also "reduced iron, containing sulphides in excess U. S. P. requirements."

We should seek coöperation from the Association of Pharmaceutical Chemists to discontinue leading unsuspecting pharmacists astray by offering them "elixir iron, quinine and strychnine," containing only 2 grains of quinine per fluidounce. I doubt if any pharmacist ever has a demand on prescription for such an elixir.

The coöperation of the Wholesale Druggists Association should be sought by requesting its members to furnish drugs to druggists, on orders for drugs under U. S. P. or N. F. titles, and not to assume that druggists are technicians who require material for technical purposes only.

I feel that you editors do not often come in touch with commercial affairs that, not infrequently, have a potent effect on the professional status of the pharmacist. A commercial representative can, in a few moments, undo much of the good a pharmacist has learned in college, and, he may do it without intending to do so.

Pitrsburgh, Pa.

Signed, L.ouis Emanuel.

\section{COMMITTEE REPORTS}

\section{REPOR'T OF THE SECRETARY OF THE SECTION ON EDUCATION AND LEGISLA- TION AMERICAN PHARMACEUTICAI ASSOCIATION.*}

Judging from past reports the objects of this Section seem to be very largely based on the study of conditions and legislation affecting the educational standards and advances and the practice of pharmacy in general, the ultimate object of the study being to bring order out of the varied conditions existing and to eventually standardize educational requirements and methods. and to obtain greater uniformity in our laws. It is obvious, therefore, that, aside from the papers presented and the discussions resulting therefrom, a survey of the progress in education and legislation must be made in order that we may determine the advances made from year to year. To obtain this information statistics must be gathered from various sources and tabulated so that we may see in a concrete form just what advances have been made. It has been the duty of your Secretary to obtain this information and as a result this report will be largely statistical.

For information relative to the progress made, we have two sources from which to collect the data, namely the colleges and the State boards of pharmacy. Accordingly questionnaires.

* Presented and referred to the Publication Committee, New York meeting A. Ph. A.. 1919. 
were sent to the deans of practically all colleges and to the secretary of every State board of pharmacy. The replies to these were not very general, in fact not over 50 percent of those to whom the letter was sent replied. The replies, however, were quite generally distributed and may therefore be considered fairly representative. In addition we have endeavored to collect as complete data as was possible, using every source of information available, but even so, no doubt some errots or omissions have been made.

Owing to the source from which the information was obtained the report may be readily considered under two subdivisions, namely, Educational Progress and Legislative Changes.

\section{EDUCATIONAL PROGRESS.}

In order to obtain the information upon which this part of the report is based, as before stated, a questionnaire was sent to the deans of the various Schools and Colleges of Pharmacy, requesting answers to the following:

\section{QUESTIONNAIRE.}

r. Give courses offered with length of each, degree given and entrance requirements for each course.

2. Give date when college opens and closes.

3. What changes in entrance requirements made this year? What, if any, changes for the year 1919-20?

4. Do you have any prerequisite requirements in your State, if so are these a part of the laws governing the practice of pharmacy or are they the result of rulings of the board of pharmacy? State briefly the requirements.

5. What suggestions have you to offer, which, in your opinion, will increase the value of the work of the Section?

Summarizing the tabulated facts from the various schools and colleges we find that sixty schools are reported.

On comparing degrees offered by the schools it will be noted that greater uniformity exists than formerly, though there is still room for improvement. Why some schools still persist in giving degrees of exceptional name and character for practically the same work other schools give one of the standard degrees is still a mystery. The only solution that seems worth while is that they sound more impressive and different from the others consequently make more of an impression on those unfamiliar with academic titles.

Fifty-one of the schools reported grant the Ph.G. degree for two years' work; forty-three give the Ph.C., degree for three years' work and twenty-seven confer the B.S. degree for four years' work. 'The B.Ph., and B.Phar., are granted by four schools, in some instances for two and in others for three years' work. The degree of Phar.D. is granted by six schools and should, as it does in most schools, represent real graduate work. It is, however, cheapened by being given for three years' of undergraduate work. The title of P.D. still survives after the repeated efforts that have been made to have it discontinued. Let us hope, therefore, that the one case may soon be discontinued. The degree of Phar.M. is granted by three schools and four grant the academic degrees M.S., D.Sc., and Ph.D. though this number probably does not include all that may do so.

For purpose of comparison we must keep in mind that the data, included in the first part of this report, was compiled from reports from sixty schools. Of this number forty-five are members of the American Conference of Pharmaceutical Faculties. Of the sixty schools listed twenty-five require high school graduation for admission to all courses and of this ntimber twenty are members of the Conference. On first thought this appears to be a most creditable showing, but on further comparison we find that these twenty schools comprise but $33^{1} / 3$ percent of the membership of the Conference; a strong argument for active work in this field.

Another interesting feature in the study of these comparisons is the fact that of the twentyfive schools meeting the universal high school requirement, nineteen of the twenty-five are State university schools or colleges. Further that all of the twenty-five, with but one or two exceptions, are connected with or are a part of some university or college.

Twenty-three of all the schools require high school graduation, or the equivalent, for admission to the courses leading to the degrees of Ph.C., B.Phar., Ph.M., or B.S. 


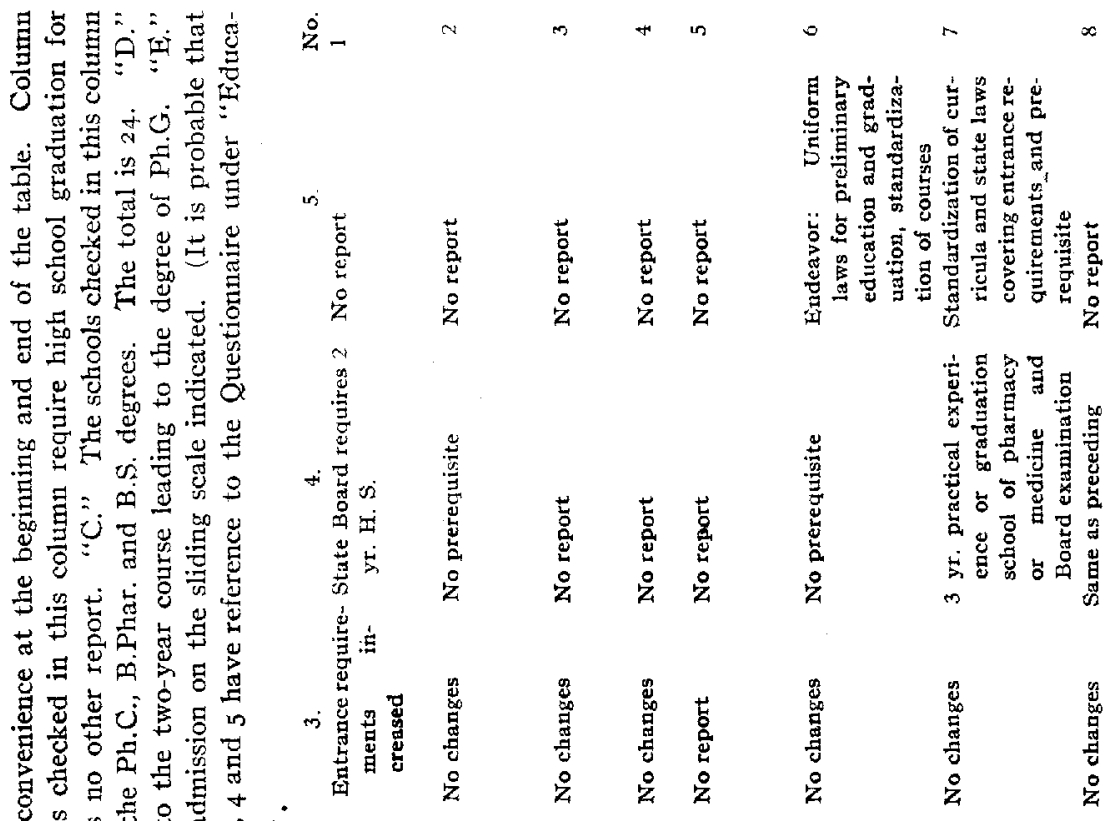

है ठै.

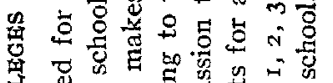

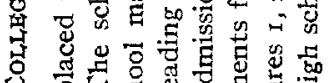

U

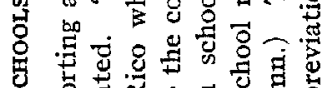

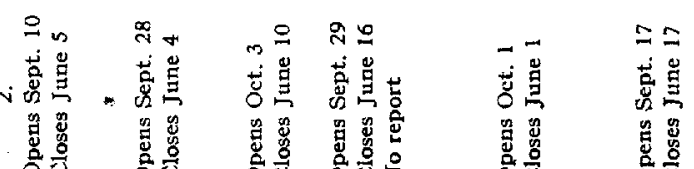

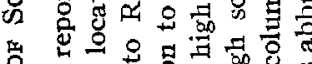

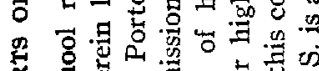

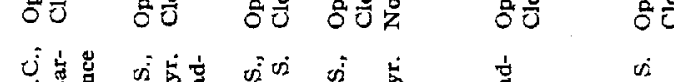

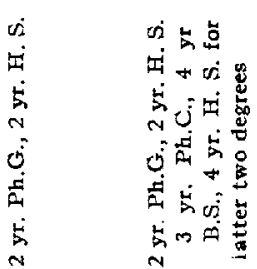

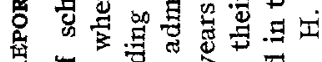

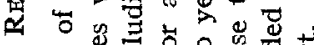

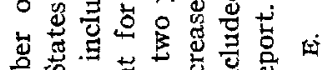

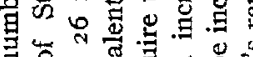

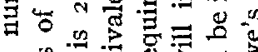

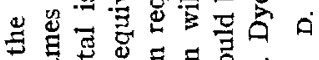

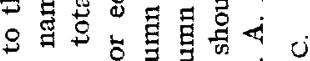

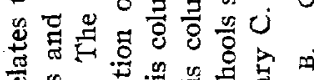

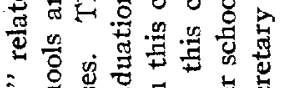

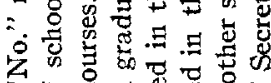

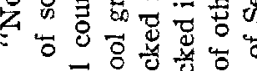

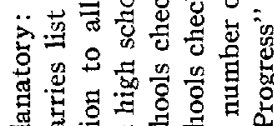

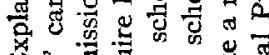

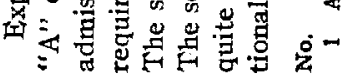

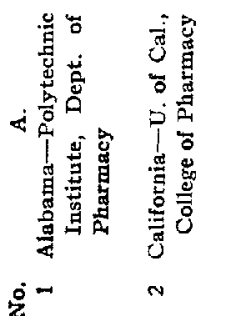

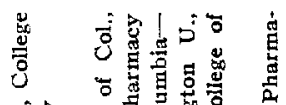

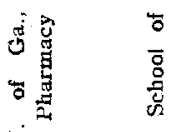

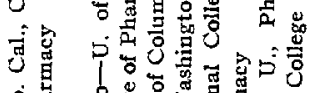

客㻤

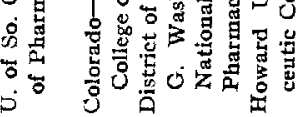

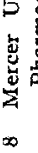



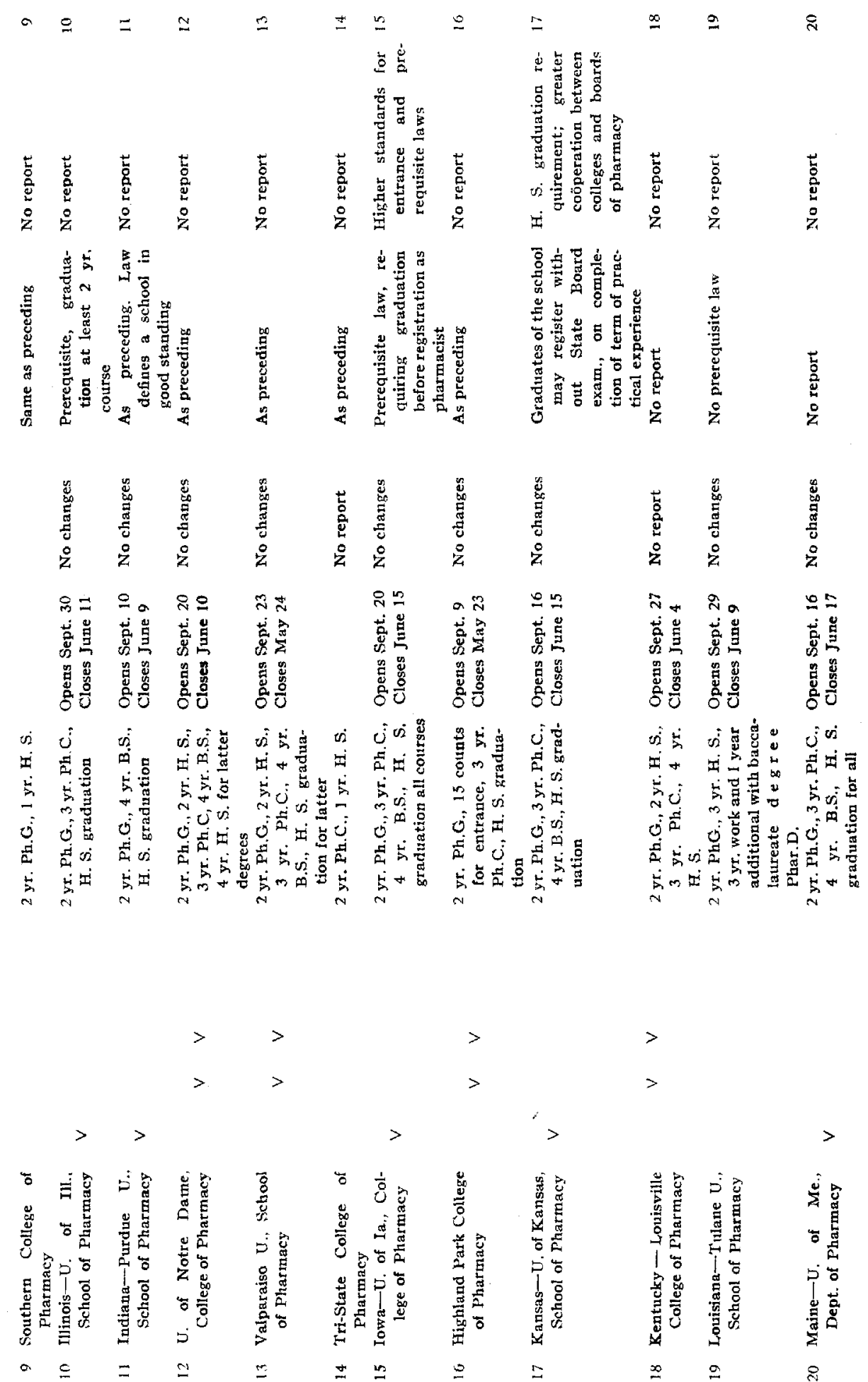


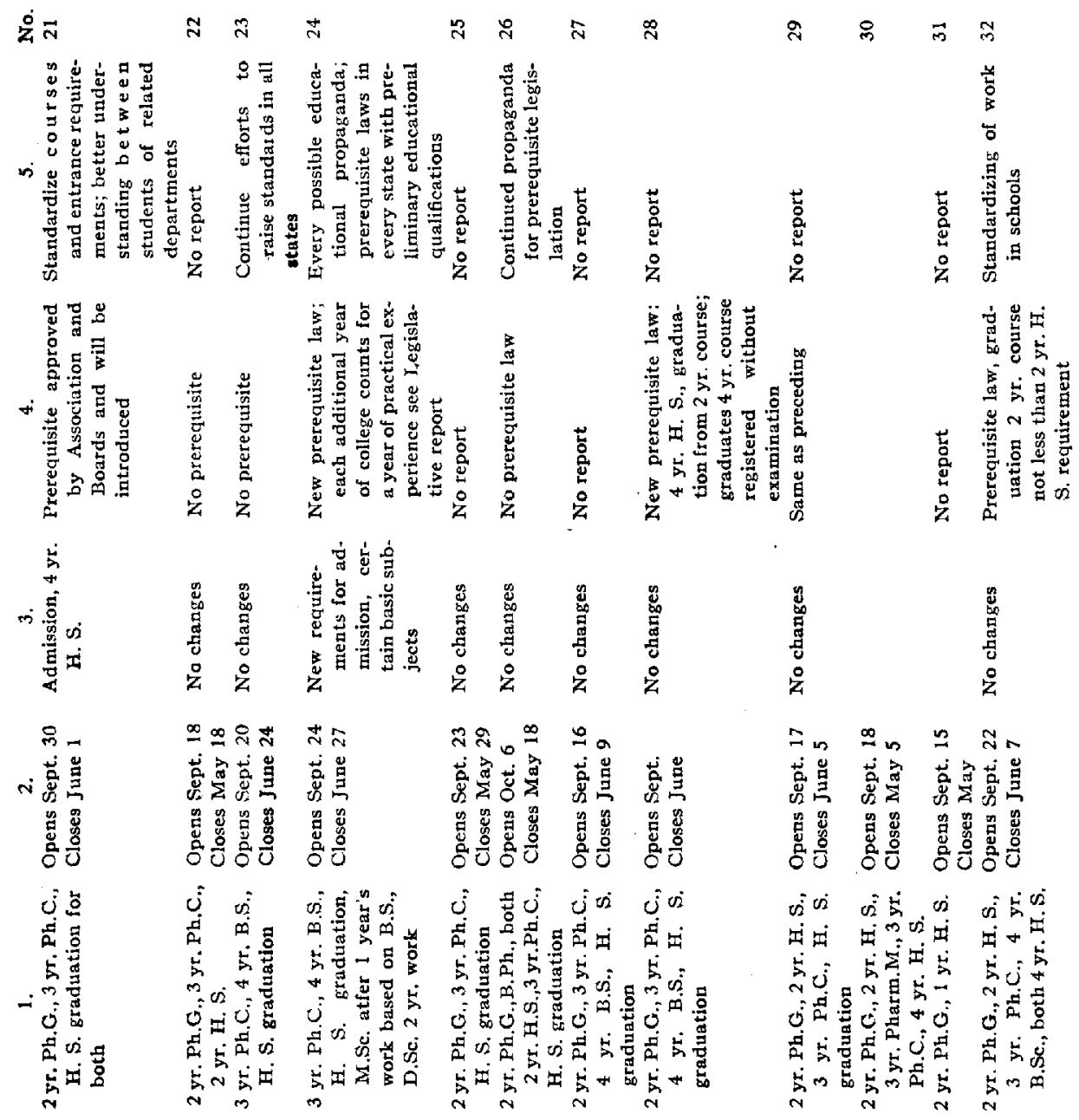

4i

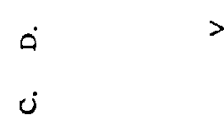

क >
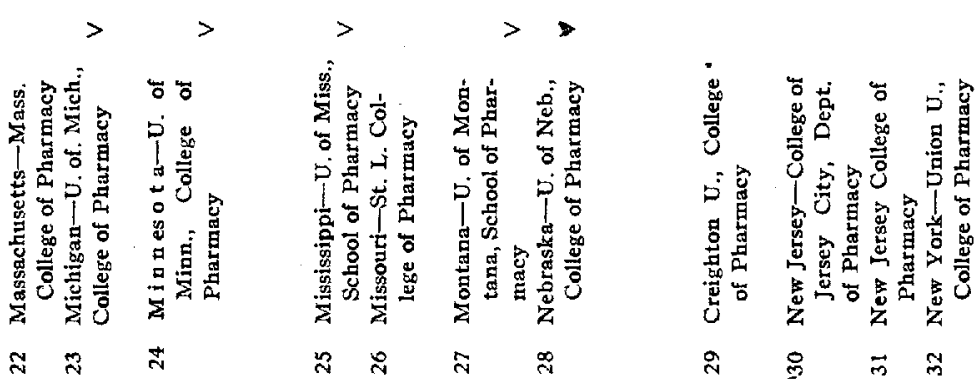

$\dot{\bar{z}} \bar{N}$

ม ก

ते ह ल लै 

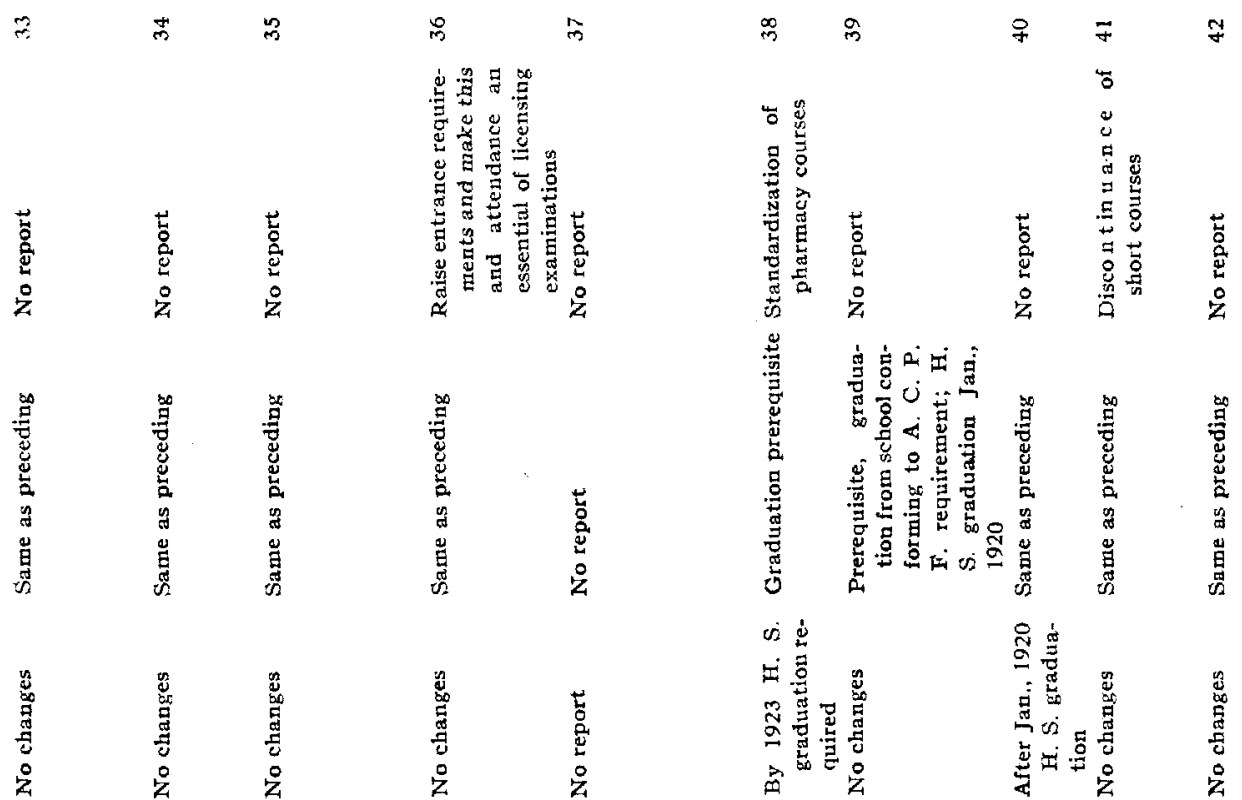

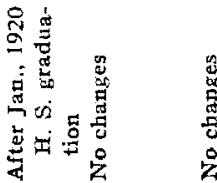

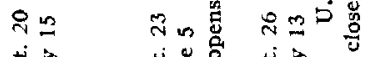

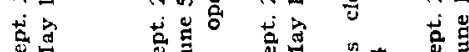

그용

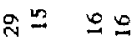

总总淧㤩

N $=20$

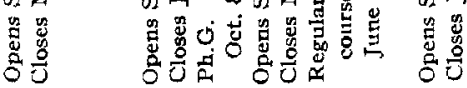

$\frac{1}{8} \frac{2}{3}$

资

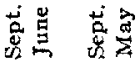

के 苟守

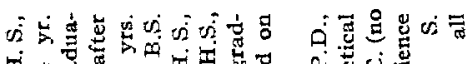

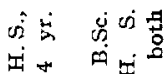

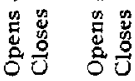

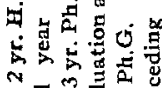
กิ

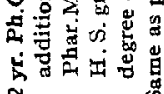

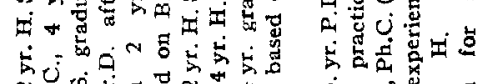

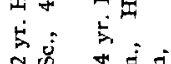

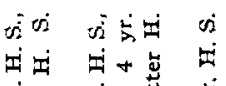

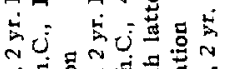

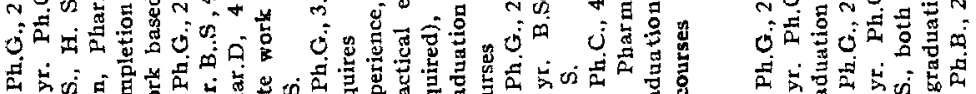

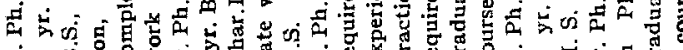

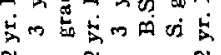
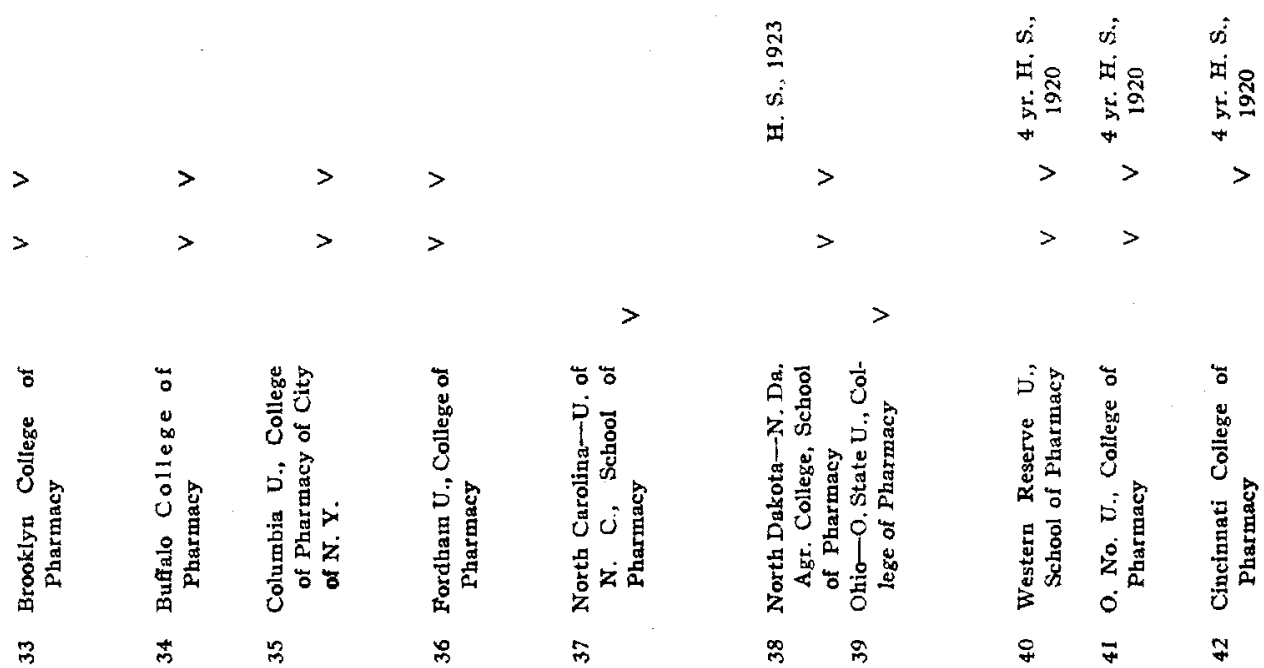


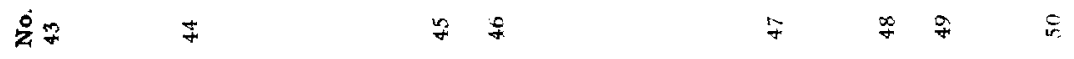

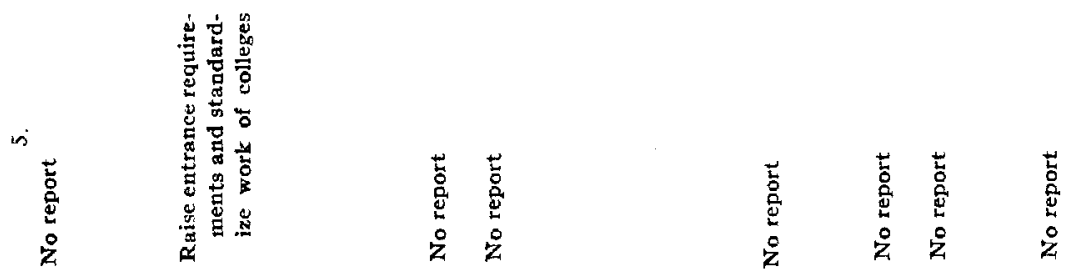
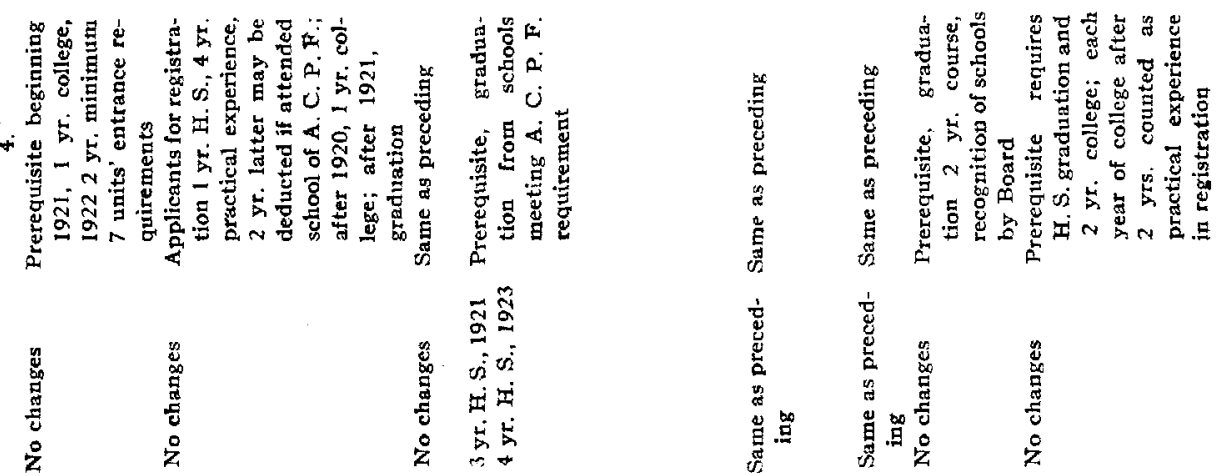

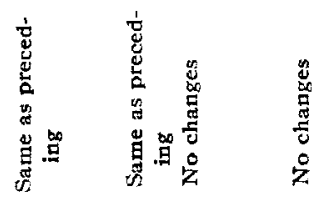

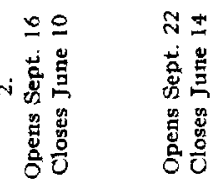

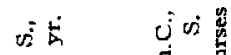

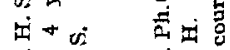

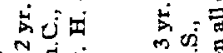

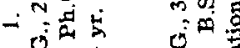

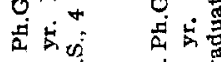

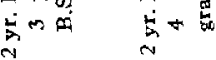

5

$\dot{0}>$
$\dot{0}>$

$\infty$

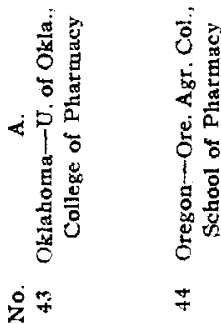

กิ

蓠语

器

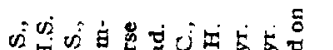

0

葛总

$\frac{18}{80}$

雨

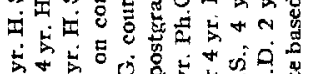

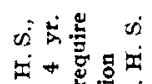

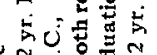

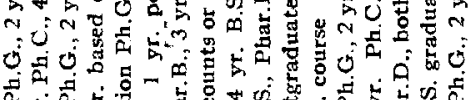

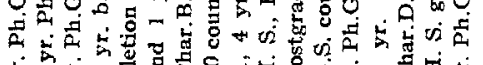

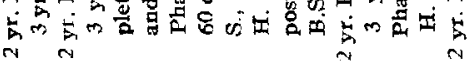

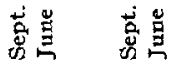

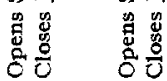

किष造的

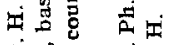

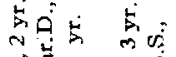

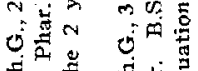

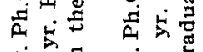

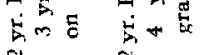

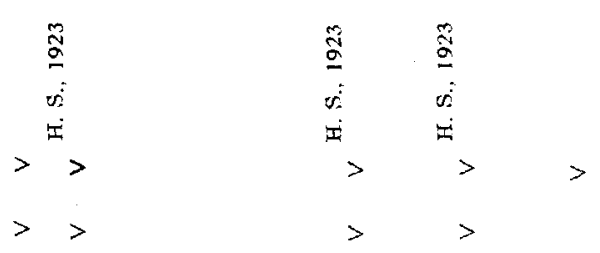

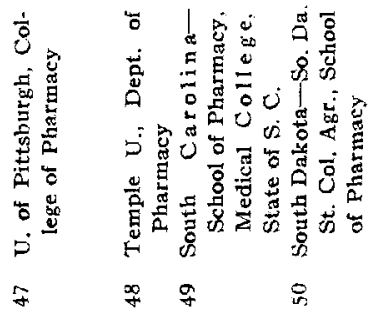



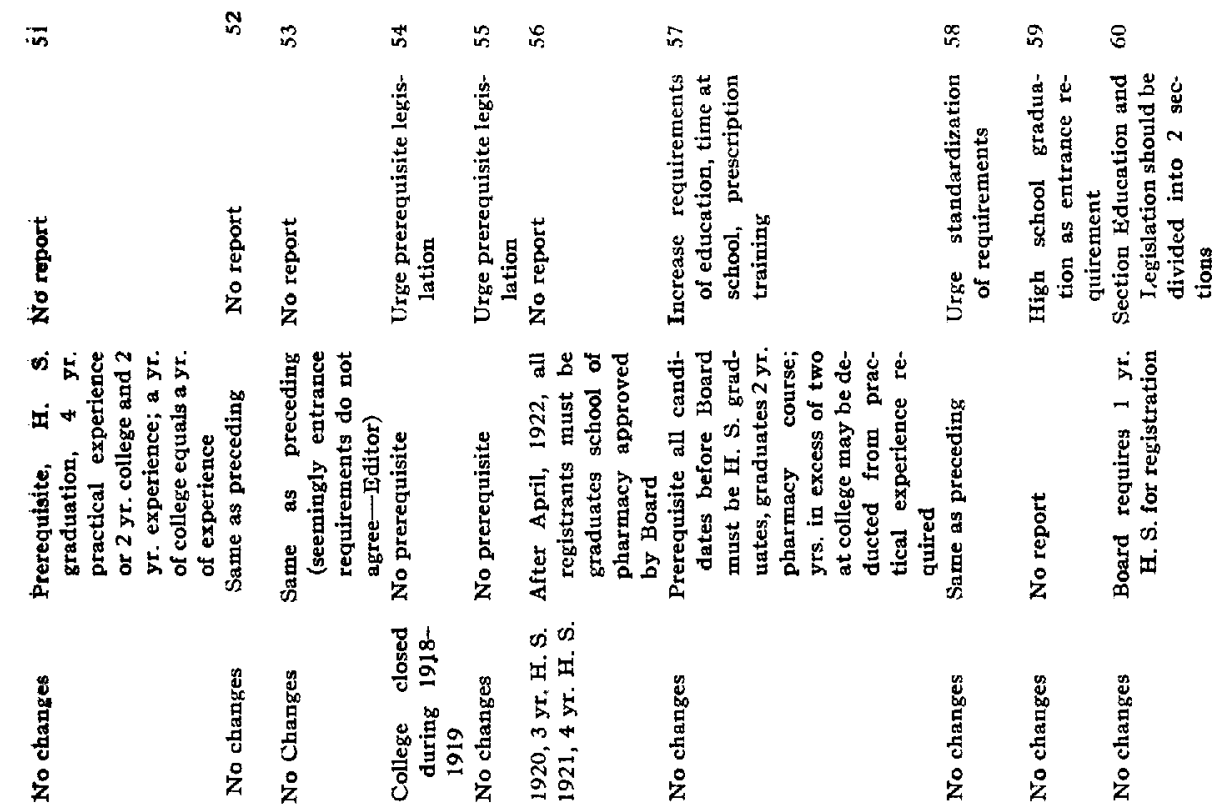

พิด

疍

งิน

กิ

$-\frac{20}{8}$

$m \subseteq \simeq 2-$

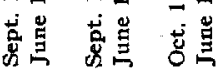

昜

8 
Only two schools, the University of Maryland College of Pharmacy and Alabama Polytechnic Institute, reported that they had raised their entrance requirements and in both instances high school graduation is required. A number of other schools reported that they have made provision for a gradual raising of standards to high school graduation. These schools will be listed later on in the report. It might be added that of these nine schools, five will go on a high school basis Jantary I, 1920 and the remaining four will reach this basis in 1923. Thirty-two schools require two years of high school for admission to the two year courses.

\section{LEGISLATIVE CHANGES}

A questionnaire covering certain specific questions was sent to the Secretary of every State Board and of these about half replied. In explanation of this fact it is possible that the Legislature in some states did not convene this year or that proposed laws were defeated and it was therefore deemed unnecessary to make any report. However, the replies received were quite generally distributed and may, therefore, be taken as fairly representative of conditions and the progress being made in pharmaceutical legislation.

The following questions were included in the questionnaire sent out, an effort being made to obtain data on those points of particular interest to this Section.

I. What new legislation was enacted in your State this year affecting the practice of pharmacy? If possible send copies of the new or amended laws. adopted?

2. Do you have any prerequisite requirements, if so what are they and when

3. Are the prerequisite requirements a part of the law regulating the practice of pharmacy or are they the result of Board rulings?

4. Have you any suggestion to offer the Committee or the Section, which in your opinion will help to make the joint session of the Boards of Pharmacy, the American Conference of Pharmaceutical Faculties and the Section more helpful to the members and the practice of pharmacy in general?

In reporting their replies they will be arranged in the order given in the questionnaire and according to states. Owing to the length of this report it will not be possible to go in to any great detail in summarizing the features of the laws and in other instances owing to the length of the laws even a brief synopsis is hardly possible.

EDIToR's NoTE.-California, Maine, New Mexico, South Dakota, Texas, Vermont, Virginia and Washington report no changes. States not reporting are omitted.

ARKANSAS.-A number of bills aiming to improve the practice of pharmacy in the State were introduced, but were defeated. The Board, however, is untiring in its efforts and we are hopeful of better things in the future. As a suggestion, why not recommend to the Bureau of Internal Revenue, the licensing of all drug stores, in charge of registered pharmacists, in each State, prerequisite to the possession, use, sale of ethyl alcohol and of narcotics, restricting all orders and prescriptions for same to the district in which they were issued?

COLORADO.- Several amendments to existing bills failed of passage. We are convinced, by long experience on the Board, that graduation from a college of pharmacy should be required of all candidates for registration.

ILI,INOIS.-New requirements for registration of schools and colleges, recently sent out. by the Department of Registration and Education, are quite broad and inquiring in scope, but are too long to be reviewed in this report.

Inoiana.-New prerequisite law enacted by the last session of the General Assembly, effective January I, 1920. 'Graduation from a recognized college is required and such school must demand as a minimum the satisfactory completion of at least two years of high school for admission. Further, the school must meet the requirements of the A.C.P.F., and the work as outlined in the Syllabus.

Persons registered as assistants or apprentices at the time of passage of the bill are exempt. Further exemptions include unregistered assistants, prescription clerks and owners, who have been actively and continuously engaged in business for ten years prior to July 1,1919 , in a town of less than three thousand inhabitants. To such persons permits may be issued under certain. restrictions; permits to be renewed every two years.

IDAHO.-New pharmacy act in which the enforcement of the pharmacy laws is placed, 
under a Commissioner, in the Department of Law Enforcement. The Commissioner apparently has the power to appoint the Board members; they must be registered pharmacists. The Board is empowered to define what shall constitute a school, college, university or department of a university; has power to establish standards of preliminary education deemed requisite to admission to a school, college or university and to require satisfactory proofs of the enforcement of such standards. The fees for licensing, registration, etc., are specified, as well as drugs to be sold by registered pharmacists, with certain exemptions for physicians. The law also permits assistant pharmacists to conduct a store in a village of not more than two hundred inhabitants when there is no pharmacist within three miles of the village. Permits of credit for college work as practical experience but not to exceed two years. Graduates of a three-year course of nine months each may be licensed without an examination. Permits of reciprocal registration, makes it unlawful for unauthorized persons to use the title of pharmacist, exempts pharmacists from jury service, restricts the sale of poisons, etc.

IowA.-Pliarmacy law amended so that an annual registration of two dollars may be collected, one dollar of this to go to the Iowa State Pharmaceutical Association to be used for the advancement of the art and science of pharmacy. Another amendment changes the reciprocal registration fee from ten dollars to the fee charged by the State from which the application is issued. Another amendment relates to the salary and traveling expenses of the Secretary of the Pharmacy Commission.

MASSACHUSETTS.-A new law entitled "regulating the sale of alcohol" is in reality a law regulating and licensing the sale of methyl alcohol, denatured alcohol, or any preparation used in manufacturing or for commercial purposes. All such products must have red label and other regulating features, license to be issued by Boards of Health and to be renewed annually.

Minnesora.-A new prerequisite law enacted by the last Legislature effective on passage. It requires at least two years of successful work in a recognized college of pharmacy and two years of practical experience for registration. One or more years of additional and completed college work may be counted, but this is not to exceed three years. Law does not require preliminary high school training, but provides that the Board may conduct an examination to test candidates' preliminary educational qualifications.

NeBraska.-New prerequisite law but unable to obtain a copy.

NEW JERSEY.--Amended law and prescribes the usual features of how the Board shall be appointed, length of service, provides for reports to the Governor and State Association, who shall sell drugs and conduct a store, requirements to be met by those applying for registration including four years of practical experience. The law provides that a credit of not to exceed two years may be granted to graduates from a school of pharmacy complying with the rules and regulations of the Board. The applicant must procure from the Commissioner of Education a certificate showing that he has a preliminary education equivalent to the standard established by the Board. The educational requirement of the Act becomes operative September igrg. Provision is made for provisional registration of those who served in the Army or Navy in the recent war. Further, all stores are required to display on a sign so as to be read from the outside the name of the registered pharmacist in charge; certificates are renewed every two years. Amendments to the poison law were also passed.

NEW YORK.-No changes except an amendment providing for the issuance of a junior pharmacist's license. This makes certain requirements as to the applicant's character and further exacts that he must have had fifteen academic counts prior to January 1 , I9r 8 , before beginning his first year in school; after this date thirty counts are required. Further, he must have studied pharmacy as outlined in the Syllabus two years and received his diploma as a graduate and had two years of practical experience under prescribed conditions all of which experience must have been in a pharmacy of New York State.

North Carol.tna.-Board of Pharmacy has adopted a definition of what constitutes a reputable school of pharmacy, which requires that the institution shall be either incorporated or a department of an incorporated educational institution or a state university. The course of instruction must include oral lectures, personal laboratory work, recitations and reviews, work in absentia excluded. The institution must require a minimum entrance requirement of two years of high school and not less than 1200 hours of instruction. The subdivision of this is practically that given in the Syllabus. Further, requires that the certificate from the school 
must show at least nine months of attendance and thirty-six weeks of actual time devoted to the course of instruction.

Also passed an Act to obtain reports on persons infected with venereal diseases. This makes it unlawful for any one except a registered physician to preseribe or give away any medicine for the treatment of venereal diseases. Druggists, or others, who sell at retail any such remedies are required to report same on special blanks to the Bureau of Venereal Diseases.

Onfo.-Pharmacy law amended to require all applicants for registration to be citizens of the United States and that on and after January 1, 1920 all applicants for registration must present as preliminary educational requirement a diploma from a legally constituted high school, normal school or academy issued after four years of study, provided, however, in the absence of these qualifications the Entrance Examiner may examine the applicant in such branches as are required. A new law provides for permits to be issued to registered pharmacists and assistant pharmacists from other states, who have been honorably discharged from military service of the United States while at war with Austria-Hungary and Germany. These permits are issued on proof of previous registration and are good for six months. Later the candidate may apply for reciprocal registration. A stringent measure governing the sale of alcohol, alcoholic liquors and other products containing them was passed.

Pennsylvania.-Pharmacy law amended to permit of reciprocal registration, provided the applicant shall produce evidence of his having had the required secondary and professional education and that the state granting the original certificate reciprocates with this state. It also provides that persons registered in other states prior to the enactment of the law shall be required to meet only the requirements in force at that time. It further provides for the Board to send delegates to the convention of the National Association of Boards of Phatmacy and permits the Board to join the Association. The bill also provides for the issuance of permits to honorably discharged soldiers and sailors to practice six months and then subsequently register by reciprocity. A further amendment permits the sale of poisons for technical use provided that the article is labeled for technical use and not intended for medicinal use and is sold in com. pliance with the provisions of a section of the original law.

South Carolina.-A law enacted to prohibit the sale and purchase of extracts, tonics, bitters, drugs and medicines or compounds containing alcohol which may be used as a beverage. The purchaser is required to sign a certificate stating " $I$ have this day purchased from.... the following preparation to be used as a medicine, toilet preparation or flavoring extract and will not myself use or allow any of same to be used as a beverage." Violation by anyone is a misdemeanor and upon conviction liable to a fine of not less than $\$$ I 00.00 nor more than $\$ 500.00$ or imprisonment for from three months to one year, subsquent offense punishable by imprisonment from one to two years.

TENNESSEE.-A new law enacted which is one of the most progressive laws we have seen. A few of the featues may be mentioned. At least three of the five members must be college graduates, the selection of members for appointment is made from recommendations by the State Association of twenty names selected from the congressional district; these are then voted upon by mail, by every registered pharnucist in the State, the five names receiving the highest vote are then sent to the Governor and from these the appointment is made. There is an annual registration fee; from this not to exceed $\$ \mathbf{I} .00$ is turned into the State Association for the advancement of the art and science of pharmacy. Such payment automatically makes each registered pharmacist a member of the State Association. Provision is made for the issuance of permits to drug dealers in small towns having a population of 500 or less and where conditions do not warrant the employment of a registered pharmacist. Such dealers may perform all the duties of a registered pharmacist, but only in the town for which the permit was granted. The Board is empowered to enforce all laws pertaining to the manufacture, sale and distribution of drugs, chemicals and poisons. As requirement for registration a preliminary education equivalent to high school graduation is required. Four years of practical experience is required for registration and in the case of assistants one year of college work may be substituted.

From some sources we have heard that college work could be substituted for the practical experience required from all applicants, but we could not find such a statement in the law. The law further provides that it shall be a misdemeanor not to have in the store the latest revision of the U. S. P. and N. F. These are a few of the many features of the law. 
Wisconsin.-Law increased dues for registration for pharmacists to two dollars and assistants to one dollar.

By a ruling of the Board, effective July 1, 1919, the preliminary educational requirements for those registering as pharmacists were increased to two years of high school. The State Association, at its last meeting, went on record as favoring a gradual increase in the preliminary education requirement to high school graduation, and to require college graduation from a recognized school for registration.

The following states now either have laws or Board rulings requiring college graduation as a prerequisite for registration: Idaho, Illinois, Indiana, Iowa, Minnesota, Nebraska, New Jersey, New York, North Carolina, North Dakota, Ohio, Oklahoma (effective 1921-22), Oregon, Pennsylvania, South Carolina, South Dakota, Virginia and Washington.

[Signed] C. A. Dye, Secretary.

\section{RFPORT OF THE PHARMACEUTICAL SYLLABUS COMMITTEE.*}

AUGUST 1919.

The Pharmaceutical Syllabus Committee respectfully submits the following report.

A well attended meeting was held at the Congress Hotel, Chicago, Illinois, on August I4, I918, at which plans for the preparation of the third edition of the Syllabus were worked out. At this meeting it was finally decided to prepare a syllabus for a third year course leading to the degree of Pharmaceutical Chemist, in which a part of the work shall be required and a part elective by the colleges offering the course. The required subjects are to be advanced manufacturing pharmacy, bacteriology, and advanced analytical chemistry; the elective subjects are to be advanced work in dispensing, pharmaceutical jurisprudence, micro-analysis, advanced botany, physiological testing, advanced organic chemistry, chemical technology, and urine analysis.

Work on the tevision has progressed very satisfactorily in spite of the disturbed conditions due to the war, and it is expected that the third edition will appear early in 1920 , according to schedule.

The Committee is made up of twenty-one members, seven of these representing the American Pharmaceutical Association, seven the Conference of Pharmaceutical Faculties, and seven the Association of Boards of Pharmacy; thirteen states are represented in the membership.

New members of the Committee have been appointed during the year as follows: Edsel A. Ruddiman, of Tennessee, from the Conference of Pharmaceutical Faculties, and George W. MeDuff, of Lonisiana, from the Association of Boards of Pharmacy. The following sub-committees have charge of the three principal sections of the Syllabus:

Pharmacy.-W. H. Rudder, Chairman; W. C. Anderson, Albert Bolenbaugh, G. C. Diekman, W. G. Gregory, H. B. Mason, C. M. Snow.

Chemistry.-J. A. Koch, Chairman; T. J. Bradley, E. G. Eberle, G. W. McDuff, O. W. Osterlund, E. A. Ruddiman, C. H. Skinner.

Materia Medica.-H. H. Rusby, Chairman; M. C. Beebe, G. M. Beringer, John Cully, E. E. Faulkner, C. B. Lowe, E. L. Newcomb.

Each of the associations represented on the Committee regularly contributes twenty-five dollars per year towards the expense of the Committee's work, and it is requested and recommended that these contributions be continued. When the second edition of the Syllabus was issued, the Committee was in debt for several hundred dollars, but this indebtedness has now been paid, and a balance is now accurnulating in the treasury which it is hoped will prevent a similar indebtedness when the third edition is issued.

The Committee realizes the difficulty of its task and that it can only hope to make each edition of the Syllabus show an improvement over the preceding edition; it is believed that the coming third edition will show a marked improvement over the second one.

[Signed] Theonorh J. Bradiey, Chairman for the Committee.

* Presented at Second General Session, A. Ph. A., New York meeting, 1919. Request for contribution complied with and referred. 


\section{WOMEN'S SECTION, AMERICAN PHARMACEUTICAL ASSOCIATION}

ABSTRACT OF THE MINUTES OF THE SESSIONS HELD IN NEW YORK CITY, AUGUST 28 AND 29 , I9I9.

In the absence of the officers of the Section, last year's President, Miss Zada M. Cooper, called the first session of the Women's Section to order Thursday, August 28, at 10:30 A.M. The presiding officer announced that it would be necessary to elect a temporary chairman, and Mrs. John Culley, of Cgden, Utah, was nominated and elected.

The invocation was delivered by the Rev. Mr. Schuchard. Mrs. Robert S. I,ehman, of New York City, Chairman of the Ladies' Committec, delivered the address of welcome, and this was responded to by Mrs. J. Leyden White, of California. as follows:

Charles H. LaWall, President of the American Pharmaceutical Association, spoke in part

I believe you have an important part in the work of our Association and there are great possibilities for this Section. Pharmacy needs the concerted effort of every one of its component parts, or units, in order to achieve greatest success. We must realize that in a federation women's work is bound to be an important factor. The hospital pharmacies are attractive to women pharmacists and therein they have been eminently successful. More women pharmacists then ever before are now engaged in drug stores; however, the hospital pharmacies are particularly well suited for the work of women, and, in late years, nearly all hospitals have shown a preference for them. There is opportunity for improvement in the conduct of pharmacies in some of the hospitals, not only greater care must be used in dispensing, but better records may be made in the handling of narcotics and alcoholics. The work of the pharmacy can also be extended, making this a better and larger service. Pharmacists in hospitals should be selected with great care in judgment of their qualifications and there are possibilities of raising the standard of education and training so that these pharmacists will advance the status of pharmacy and benefit the practice of pharmacy in general.

Dr. J. H. Beal presented the following paper:

\section{WHY THE WOMEN'S SECTION?}

Since the American Pharmaceutical Association provides a section for the consideration of technical scientific subjects, a section for the consideration of commercial problems, a section for dispensing problems, and other sections for the various other special features of pharmaceutical practice, the questions are sometimes asked, What is the necessity for a Women's Section? and, Why cannot women who are interested in pharmacy find full scope for their activities in attending and taking part in the proceedings of the other Sections?

To these questions there are a variety of answers.

The first answer is that it is one of the purposes of this Section to openly emphasize the work of women in pharmacy, and to afford the American Pharmaceutical Association the means of recognizing women's pharmaceutical activities in a more public and emphatic way than could be accomplished by merely granting their right to general membership.

That women realize a necessity for some concrete recognition of this kind is attested by the various independent associations of women pharmacists that have from time to time been projected. Those who entered these independent organizations were eligible to membership in the regular pharmaceutical organizations, but they realized, and justly so, that the sisterhood of pharmacy needed some means of expression beyond that which they could receive in organizations created by and mainly conducted by men.

The women members of the American Pharmaceutical Association are entitled to attend and take part in the proceedings of any or all of the other sections, but no matter how cordially they are received there, they must always have a consciousness that they are regarded more or less in the light of visitors, welcome visitors no doubt, but still visitors. In this their own Section they can feel at home, and here the male member of the species if he is present must accept the role of casual attendant.

A second reason for the existence of such a separate section is that there are questions connected with women's work in pharmacy which affect women primarily and directly as such, and upon which they should pass independent judgment.

What should be the general nature of women's employment in the drug store, what classes 
of goods in the retail drug stock should women be expected to handle, and what goods should they be excused from handling, what should be the length of the hours of their service, should they be required to work on Sundays or be exempted, how should the rate of their compensation compare with the rate $o$ ? compensation of male clerks? - these and others are questions in which women have a direct and primary interest and upon which they should voice their well considered conclusions independently, after which it will be appropriate for them to submit their conclusions, if necessary, to the general association.

We are living in a time when woman's right to participate in all the multifarious occupations of life is rapidly approaching universal recognition. That it has not been earlier recognized has not been due to the stubborn unfaimess of the other sex, but to woman's own lack of assertiveness. She has been content to tag along after the chariot of the male and, indeed, has often voiced her preference for such secondary and subsidiary position.

Privileges cannot be accepted without asstuming their attendant obligations. If women claim the new privileges, they must demonstrate their ability to stand alone and to think and act independently upon questions which peculiarly affect their interests. The opportunity for the independent voicing of their opinions upon such subjects is afforded by the Women's Section, while at the same time the other sections of the Association are open for their participation in the discussion of questions of common interest to both sexes.

A third important reason for the Women's Section is the fact that the annual meetings of the Association are largely attended by women who are not themselves members, for which the regular programs of the Associations provide no duties except attendance upon the functions commonly set down under the head of entertainments. While these attendants may not care to take part in the work of the regular Sections, yet many of them are averse to being considered as fit only for the diversion of theatre parties, card parties and the annual ball. Though not themselves qualified as pharmacists, they have a lively interest in the progress of pharmacy as a vocation, and are prepared by their influence and counsel to aid those of their sex who have adopted pharmacy as their life work.

The Women's Section affords these non-members the opportunity of a place where they can feel free to exercise their efforts in a helpful and constructive way. In this respect it plays the part of Women's Auxiliary, but it was thought wise to make it something more than a mere auxiliary by giving it an organic connection with the parent body in the form of a section coequal with the other sections.

A fourth reason for the Women's Section is that by its separate existence it has an opportunity and an incentive to emulate the other sections in securing new members for the Association.

The crying need of the American Pharmaceutical Association is a greatly increased membership. Many important projects are curtailed, and many others are unattempted, simply because the present membership of the Association is not sufficient to warrant such undertakings.

Experience has shown that the women of the Association are peculiarly successful in obtaining new members when they are willing to make the effort, and besides there are hundreds of women pharrmacists who are not members of the American Pharmaceutical Association, but who would become such if they received an invitation from the Women's Section.

During the year the number of new members brought into the Association through the efforts of the Women's Section were equal to nearly half of the new members secured by all the ather Sections combined.

Here is an opportunity which, if utilized, is of itself sufficient argument and excuse for the separate existence of this Section.

Many other equally good arguments might be offered for the existence of the Women's Section, but the preceding are some of the indications of its possible utility to women in pharmacy, and to the American Pharmaceutical Association. Many of the thoughtful members of the parent association regard this section as one of the most promising divisions of the Association and hope for its development to larger proportions and to greater activity than it has yet assumed.

To use an expression originally introduced as slang, but in a fair way to recognition as good English, "it is up to you" to show that woman's capacity for independent organization and for constructive work in pharmacy is a real and substantial entity and not an empty myth. 
The Section expressed appreciation and thanks to President LaWall and Ex-President J. H. Beal, and the address and paper were referred to the Publication Committee.

The address of President Anna G. Bagley was read by Mrs. John G. Godding. It follows:

\section{ADDRESS OF THE PRESIDENT OF 'THE WOMEN'S SECTION, A. PH. A.}

To the women of the American Pharmaceutical Association I send greetings and good wishes, regretting sincerely that $I$ am not able to be with you this year.

The past few years have not permitted the usual association activities, but it is needless to recall here our trials and sufferings of that period or the one great joy that in some slight measure compensated for its sorrows. None of us are blind to the great lessons taught to the world through the sufferings endured. The point of interest now is, how shall we profit by those lessons and keep the war won?

The American woman has always enjoyed a more exalted position than her sisters in other countries; she has exerted a powerful influence in religious, social and political life. In religion and social affairs, and especially in the home, she has been the dominant factor; her political influence until quite recently has been indirect. Her high ideals and her secure position in the home have been the source of that influence.

Some years ago, however, women began to realize that the usual activities in religious and social affairs did not meet the demand. There were changes taking place. New ideas and new ideals were making new conditions which called for organized effort if church and home were to be kept the center of inspiration and good influence. Organizations then began to grow and as the evolution progressed women were drawn into political affairs, first regarding educational matters only; then later, and now by degrees, they are being drawn into direct contact with political affairs, carried by a current which they are unable to resist, into which each woman must throw her effort if she would protect herself and her home.

The manner in which women answered the call to the colors and the restlts which they accomplished are conclusive proof of woman's ability to spread her good influence into broader channels without in the least lessening her interests in the home and social circles where she has so long been content to reign.

I say this new condition is a thing outside of and beyond our power to control; it affects the women of every other country as it does those of America and we must cope with it or be outselves crushed and see all those things for which we have stood so valiantly put away.

Coming now to the more concrete case of the women in pharmacy, which does not only mean those women who have prepared themselves for the duties of the professional pharmacist, but all those who through their husbands, fathers or brothers look to pharmacy for a livelihood, as well as the woman pharmacist. Whatever touches that profession, whatever touches business in general, also touches these women. Therefore if they have recognized the call for public or semi-public service which has gone out to all women, it is their duty to put the first of that effort in the channel which leads to pharmacy, and the Women's Section, as I see it, was designed to be that channel.

Much of the progress toward modern ideals is delayed through lack of participants. There is many a woman whose reasoning is good, who is modern and progressive and who believes in this new cause of women to-day, but she hesitates to put her hand to the wheel because she has never done so; she is timid and fears criticism; I can sympathize with that woman, for I have felt the same way and do yet about some things. But where I have been able to overcome that feeling and given what I could to some public or business cause, there has come a satisfaction in having endeavored to push a good thing along and a feeling that I have been drawn out of myself. I am sure we have many women like that in our Section. 'They do not refuse their assistance because they do not believe in the work, but are perhaps not well posted upon A. Ph. A. affairs and are conscientious about undertaking it.

Let me say that no woman whose interests are in any way bound up in pharmacy is going to make any very serious errors in doing section work in the A. Ph. A. It is all plain drug store tactics. Just try it and see!

The only thing this section lacks to make it a great success is coopperation. Some men who are not in the A. Ph. A. are afraid of it because they think it is a "high brow" organizationwhatever that may be-but it has been my pleasure to watch several men out of this class join 
the A. Ph. A. and become, well-not only enthusiastic-but real A. Ph. A. fans. And the same thing will happen to the women once they get started to work in this Section.

Many do not understand just what we are driving at in this Section, and I cannot better state it than did Dr. J. H. Beal when he addressed the Women's Section at Nashville, when he said:

"There is a work that you can do that cannot be done without you. We men feel that we are capable of handling the coarser, heavy work of the Association, but we believe that there is a finer quality of work that can be done by the Women's Section that you can better accomplish. We welcome you most heartily as our coadjutors in making the A. Ph. A. conserve the best traditions in pharmacy, and not to be only a conserver but a developer of what ought to be our common aim."

It has taken us some time to put our finger on that more delicate service but we feel sure we have solved that point largely by the program so ably planned by Miss Zada Cooper in her address last year. We have had many excellent suggestions for work, but I believe that was the first workable, concrete program set before us and I am grieved that my administration could not grasp its opportunity.

It may not be amiss to state that there are many grave dangers facing the drug business at present and I believe any work which this Section can do which will reach the laity will help decrease that danger. Publicity of the right sort directed to the laity would have a great value and if the Women's Section did nothing more in the coming year than operate a publicity burea1, the whole drug field would feel its effects. What little has been given to the laity has come from wrong sources and is, therefore, mostly wrong.

There have been many difficulties in the way of perfecting the organization of this Section, but I feel we are sufficiently well organized now to undertake the program mentioned above and with some hope of accomplishment. War work has taught many women never to have an idle moment and if we could have a few of those moments devoted this next year to Section work, a wonderful good could be accomplished. If each would do her bit, the work could be carried on without burdening any one.

$I$ have read over the proceedings of all our meetings and with what acquaintance I have with present conditions in the drug business, I feel that the very comprehensive program which was submitted to you last year, and which war conditions prevented being carried out, will be the best program we could devise.

I would therefore recommend that we re-adopt the recommendations in Miss Cooper's address:

x. 'Ihat our Press Committee be instructed to get brief articles about the op-

portunities for women in pharmacy into high school magazines.

2. That our Outlook Committee be instructed to reach club women in whatever way seems most feasible with similar information.

3. That our Secretary be directed to communicate with the President of each

Women's Auxiliary of the various state pharmaceutical associations urging each woman in her own locality to make an effort to reach high school girls individually and through local women's clubs, or druggists' associations.

I would further recommend that each woman present pledge her assistance when asked, responding promptly, and to carry the message of the Women's Section to all her associates in pharmacy.

I would recommend that all women of the $\mathrm{A}$. Ph. A. read the Association Journal.

I would recommend that each woman seek members for the $\mathrm{A}$. Ph. A., with a full knowledge that the greater benefit goes to the member in the possession of his membership than to the Association.

Heretofore the retiring President has made the appointments for the following year in. order that the Section might have the benefit of her experience. Last year we adopted a new set of By-Laws and I am uncertain whether this procedure is to be continued under the new law. If so, I will gladly make these appointments.

I wish to thank the officers and nembers who have responded to my call for help, and especially to Miss Cooper, who has so kindly consented to look after my duties during the convention. 
I have appreciated the honor of being your President and shall always regret that circumstances over which I had no control prevented making this past year a record one for accomplishments.

ANNA G. BAGLEY.

The address of President Anna G. Bagley was referred to a committee of Miss Adelaide Rudolph, of New York, and Mrs. John G. Godding.

Mrs. John F. Hancock, Honorary President of the Section, expressed her appreciation of the honor conferred.

The following committees were appointed:

Committee on Resolutions: Mrs. H. M. Whelpley; Mrs. J. Leyden White.

Committee on Nominations: Mrs. John G. Godding; Mrs. R. S. Lehman; Mrs. Gammon.

The first session of the Women's Section was then adjourned.

SECOND SESSION.

The second session of the Women's Section, A. Ph. A., was called to order August 29, at 11:00 A.M., by Mrs. John G. Godding. The report of the Secretary, Mrs. Hampton Ray Kenaston, was read by Miss Zada M. Cooper. It follows:

\section{THE SECRETARY'S REPORT.}

To the President and Members of the Women's Section of the American Pharmaceutical Association:

It affords me great pleasure to again send greetings to the officers and members of the Women's Section of the American Pharmaceutical Association and to offer for your consideration my third annual report as your Secretary.

I regret most sincerely that $I$ cannot attend this meeting, for experience has taught me that the benefits for those in attendance are of lasting value and the loss to me is greater than can be estimated. Though absent, my best wishes are with those assembled and my prayer is that this meeting may be the most successful yet held; may God's richest blessings attend your deliberations and may Divine power direct the great work for which you have come together and which this Section must accomplish.

It is with great interest and intense pleasure that we note the continued and increasing demand for women pharmacists in the retail drug business, in the wholesale business, in the educational and in the scientific laboratories, colleges and manufacturing institutions, the research work and the experimental work of the pharmaceutical profession. There is no question but that the Women's Section of the A. Ph. A. has had a great influence in developing the objects for which it was originated, and with the requirements for the educated women in the field of pharmacy, shall we not redouble our energies to make this influence greater from year to year?

Your Secretary earnestly trusts that a portion of the amount of funds available for the use of the Section may be voted by this meeting to the carrying out of the plans as adopted at the 1918 mecting. Your Secretary has made a strenuous effort to do her duty in reaching the young women who are about to select their life work, placing before them the advantages in selecting the profession of pharmacy, but the work has not proceeded with the dispatch that it would have done had an amount been assigned for this purpose and that amount judiciously applied. With the exception of having official stationery provided, all other expenses have been met from personal money. While I was pleased to do this so far as I could, I did not feel privileged to ask others to assist me at their own expense. The years of 1917 and 1918 each incurred extra expenses in connection with the revision and printing of the by-laws. If it meets with the approval of this meeting, it would be practical to devote a part of the funds to the obtaining of results along the lines for which the Section was formed.

Your Secretary is pleased to report that printed copies of the Revised By-Laws have been made and a number have been mailed out. A copy was enclosed with each official letter unless the person addressed had previously received a copy and also a complete copy appears in the printed minutes of the Chicago meeting. The report of the Committee on Revision of by-laws was accepted and adopted by the Women's Section August 14, 1918, but because of an oversight, same was not presented to the Council of the $\mathrm{A}$. Ph. A. for their action at the 1918 meeting and it must be presented at the New York (1919 meeting) for approval of the Council. A letter from Editor E. G. Eherle, explaining this matter, was received by your Secretary, in which it was stated that the By-Laws could be presented to the Council for action at the 1919 New 
York meeting. This matter should have consideration at the proper time during the progress of the A. Ph. A. meeting.

The constitutional duties of the office of the Secretary-Treasurer have been performed. Many letters of interestandinquiry have been received and the work accomplished by the Women's Section has been most highly commended, which commendation and approval is most gratifying. Though the work of the office is arduous, every duty has been a pleasure to perform.

There are many recommendations that occur to your Secretary as of intense value in promoting the work of the Section, paramount of which is continuing along the same outline as has been followed from year to year and especially emphasized and adopted at the Chicago meeting. If our work functions well, it must be accomplished, not by adopting new ideas and dropping the old, but by becoming more and more efficient in the work as we find it of the greatest advantage. However, those in attendance at the meeting are the proper ones to select the program for the coming year's work, and your Secretary is pleased to leave it with them.

The profession of pharmacy is one for which women are especially adapted; light, clean, neat and healthful work that any girl of average intelligence can make a success of and that with but a comparatively short course of college training, become efficient and commanding a good salary.

This report must of necessity appear somewhat indefinite as to figures, because all printing of letter heads and of the By-Laws was looked after by our President, and the printing of the minutes, together with the reprints of same, was directed by Editor E. G. Eberle. I am pleased to acknowledge the kindness and to express my very great appreciation for the assistance thus rendered.

To our President, Miss Anna Bagley, I extend the most cordial thanks for her kindly assistance and direction in the details of the work of the office. She has been ever ready to share the work insofar as was possible for her to so do.

In conducting the necessary work of the office I have written 278 letters and 65 post cards.

Your Secretary is deeply grateful for the privilege of serving the Section and desires to give public expression for the uniform kindness shown her and for the kindly coöperation in all her official relations; all have shared with me in whatever effort has been made.

Fraternally submitted,

\section{(MRS. H. R.) JEAN MCKeE KENASTON. Secretary-Treasurer.}

Letters were read from Mrs. C. A. Dye, Mrs. E. A. Ruddiman, Miss Bertha Ott, Mrs. George D. Timmons, and Mrs. Tom Carpenter. Greetings were read from Mrs. W. L. Dewoody, as follows:

"The joys I have possessed are ever mine; out of thy reach, behind eternity, hid in the sacred treasure of the past, but blest remembrance brings back." (Dryden.) So though absent in body, my mind and heart are truly with you to-day. I am living over the pleasant meetings I have attended and enjoyed so much, I must say doubly enjoyed, because my dear husband's mind, heart and hands were wrapped up in Pharmacy and the drug business-from this source he had not only realized a competent living, but also his pleasure and entertainment. He looked forward from year to year to the meetings with pleasurable anticipation of a happy time, a season of relaxation, a reunion with loved and congenial friends, and to adding something more to his storehouse of pharmaceutical knowledge. So, while I had a separate and distinct pleasure in these meetings, my appreciation was much enhanced by his zest and enjoyment. I sometimes wonder if, looking back from the other world, he does not keep in touch with his old love, the drug business. Without him my life is just half, but I find no time to stop and brood, and know that the greatest respect I can show him is to try and carry forward his wishes and to finish as nearly as I can what he had begun.

These are no ordinary times, but very extraordinary - a season of wonders-the impossible (?) accomplished. The war has made unbelievable strides in the perfection and use of aeroplanes and all other war devices. Pharmacy and surgery have not lagged in this wonderful world advancement. Our wounded and disfigured soldiers have been healed and made over in a way utterly impossible a few years ago. But none of these things have gone forward any more rapidly or wonderfully than has woman. The war has developed her marvelous capability and adaptability, it has shown how diverse and efficient her capacity. It has shown what a bulwark of power she can be in case of emergency, and how varied her undertakings and how suc- 
cessful in most instances. It is not necesssary for woman to take and keep man's place in the world; there is an individual and fitted niche for each, but it is a glorious thing for her to be able to rally to emergencies (and they come in peace as well as in war) and to fill his place when he is disabled. But God forbid that the ballot, or "equal rights," or business capacity, or anything else, may render her mannish or coarse or aggressive. While we appreciate brains, business capacity and competency to make a living, we do not want it in exchange for the modesty, the timidness and lady-like gentleness of our grandmothers.

It has always seemed to me that if there is a business in the world for which a woman is peculiarly adapted it is pharmacy. We know she excels in routine work, she is careful in minutia, she studies cause and effect, and is more careful of details. Man's reason and judgment are better, he invents and develops wonderful things, but it depends upon woman to do the things that require accurate and perfect manipulation; nothing too small for her whole attention. So. it seems woman is not the inferior or superior of man, but, to speak in terms of Geometry, is his complement. It takes both to complete God's plan for a perfect humanity-two, to make one thorough-going human machine. Christ spent His short life on earth in humble service to. humanity; His slogan was, "Serve ye one another;" "Love ye one another." Universal brotherhood is the woof and web of Christianity.

This fearful world carnage has been too dreadful to dwell upon, but it has brought us selfforgetfulness, it has brought us to serve and to give, it has strengthened the principles of democracy, it has broadened and deepened and strengthened the tie of brotherhood. "Serve ye one another"- "Love ye one another" is the one thing that will make this life worth living and will give us a passport into the glorious life eternal.

I wish for the Women's Section of the A. Ph. A. many years of pleasure and usefulness, and may your influence for good be acknowledged throughout Pharmacy.

From one who loves and appreciates your efforts.

$$
\text { (Signed) MARY SORRELLS DEwOODY. }
$$

The Committee on the President's Address reported that the recommendations of the President be approved, and the Section voted to adopt.

The Committee on Nominations reported as follows:

Honorary President, Mrs. W. L. Dewoody, Pine Bluff, Ark.; President, Mrs. F. J. Wulling, Minneapolis, Minn.; First Vice-President, Mrs. L. F. Kebler, Washington, D. C.; SecondVicePresident, Mrs. George Blakely, The Dalles, Ore.; Third Vice-President, Mrs. J. Leyden White, of Brooklyn, N. Y.; Secretary-Treasurer, Mrs. Hampton Ray Kenaston, Bonesteel, S. D.; Historian, Miss Bertha Ott, Cincinnati, O.; Chairman of the Executive Committee, Miss Anna G. Bagley, Columbus, O.; Member of the Executive Committee, Mrs. C. B. Jordan, LaFayette, Ind.; Chairman Membership and Press Committee, Mrs. John Culley, Ogden, Utah.

A paper was presented by Miss Adelaide Rudolph, of New York City, entitled:

\section{AN APPLICATION OF THE OLD CREATION STORY TO WOMEN AND PHARMACY.}

M. Cadet, founder of the Bulletin de pharmacie, forerunner of the Journal de pharmacie et de chimie, has given us a lively picture of the attitude of the pharmacentical profession towards women in 1814 . I think you will find it interesting. So I have made a translation of it to read to you. It is entitled: "Des Femmes dans l'Exercice de la Pharmacie." (Concerning women in the practice of pharmacy):

"Madame B., widow of Dr. B., a provincial pharmacist, has written to ask us," says M. Cadet, "whether she can be admitted anywhere to take the examinations required for the practice of pharmacy." M. Cadet replied with the following letter:

"Madame, there are few women to whom pharmacy appeals sufficiently to make them care to give it special study. You, were acquainted, you say, with botany before you were married, and you took a course of chemistry in Paris under our illustrious Fourcroy, and your worthy husband, whom you now mourn, took pleasure in fostering your taste for these pursuits by giving you a knowledge of pharmaceutical preparations, so that you now believe yourself ready to answer the examination questions, if the rules of pharmacy allow a woman to be admitted as a candidate. You think the law unjust which permits the widows of pharmacists to continue the business only a year, until a purchaser of their shop can be found, and you say to me: Why should not women 
be received as men, if they show the same ability? Do not the Sisters practise pharmacy in most of the civil and military hospitals, and are not the Sisters very ignorant? I must confine myself, Madame, to the reply only, that, if the Sisters practise pharmacy, it is a grievous abuse against which there has been universal but vain protest; that these Sisters, thus, as you say, not knowing anything about the Latin language, can neither consult.authors who have written in this language nor translate from the Latin, and consequently cannot fill correctly the prescriptions of physicians; that the schools would not consider it wise to admit a woman, though the law is silent in this regard, because in default of a law, custom has established that what you propose is against every form of usage.

"As you have devoted your leisure to more serious studies than those with which your sex is ordinarily employed, permit me, Madame, some historical citations which are not foreign to your pretentions. Among the ancients, pharmacy was not distinct from medicine; whoever practised one practised the other. Now, the history of the art of healing presents to us several celebrated women who made this art a profession. Artemisia, queen of Caria, cultivated medicine with success; Aspasia, the Phocean, the mistress of Cyrus and Artaxerxes, wrote upon this science. Cleopatra has left us a treatise on the maladies of women; and, finally, Agnodice, the young and beautiful Athenian maiden, disguised herself as a man in order to study and practise medicine. The pliysicians, deceived by her disguise, accused her of entering the homes of women for evil purposes. Agnodice, cited before the tribunal, proved her innocence and her sex by the assistance of the ladies of the best families of Athens, who were parties to the lawsuit. After several hearings the Areopagus, not less convinced of the merits of the accused than touched by her charms, accorded her the frec exercise of her profession and even gave other women the opportunity to cultivate medicine.

"We are not so gallant as the Areopagus, and if women among us sometimes effect wonderful cures, it is not with the title of doctor. No more have they the right to practise pharmacy; and the remedies which they administer to us, though very sweet sometimes and very efficacious, are always due to an empiricism more or less without the law.

"I know, Madame, critics so severe as to hold that a woman, however well instructed she may be, is out of place in a drug store. One cannot ask, say they, for certain remedies, without acknowledging at the same time certain diseases, which a man might willingly talk about to his physician, but which cannot be confided to a lady without causing her embarrassment. In Germany, Prussia, England, and Russia, it is rare to see a woman in a pharmacy. This place seems too hard for them. But this exclusion is not according to the custom of France.

"Many of our profession are to be congratulated on having entrusted to their wives the care of the commercial details of their houses, and the public does no less justice to their modest grace and their affability. They abstain carefully from prescribing for the sick and take no part in the manipulations of the laboratory. There are many preparations, however, that add to the well-being of life, which require only dexterity, patience and neatness. These are adapted to women, and it is to these simple preparations that they ought to limit their efforts in practical pharmacy.

"Thus, Madame, usage, opinion, propriety, and even reason are opposed to the desire that you have of presenting yourself for the examinations. You cite in vain the celebrated Laura Bassi, who received the degree of doctor at Bologna, the learned Agnesi of Milan, who sustained at nineteen a hundred and ninety-one theses, the collection of which was published; the schools of boards of pharmacy, without a new law, would not consent to question you or sign your certificate. However the love of the sciences may dominate you, a career in these is not open to you. You can, Madame, work in your study or in your own laboratory, edit your observations, write memoirs, and place your name beside those of Mesdames d'Arconville, du Coudray, Dupiery, Foucquet, Guyton de Morveau, and I,epaute. ${ }^{1}$ The Parnassus of women is already

1 Women of about that time who had published treatises and textbooks upon medicine, chemistry, and other scientific subjects. 
very illustrious. There is lack, however, of women pharmacists, and I know there is not a chemist who would not do himself the honor of giving you a hand to help you to climb.

$$
\begin{aligned}
& \text { I am with respect, etc., } \\
& \text { Bull. de Pharm., 6. C." 564-68, I9 } 4 \text { - }
\end{aligned}
$$

Whether this was a bonafide letter, I do not know-or just a concoction of $\mathbf{M}$. Cadet's written in a kindly, satirical vein. His historical references give one that impression, for they are certainly disconcerting as to accuracy.

However, M. Cadet is dead, and many other Frenchmen and other men of his time and other times are dead, and their opinions and prejudices are dead with them! And this is a new world! And women not only have the opportunity, but even are urged to come out and help to make another and better world as they will.

What wonder, then, if the mind reverts to that old creation story as told by the Hebrew seer:

"And the earth was without form and void, and darkness was upon the face of the deep. And the Spirit of God moved upon the face of the waters." And He said: "Let there be light, and there was light," and He divided the day from the night, and the land from the sea, and filled them with life, and clothed them with beauty. Then He rested and saw that all was very good; but-we will not concern ourselves with the resting part yet!

It is a picture full of energy and cheerful acceptance of a situation and making the best of it without looking around for a more desirable place in which to begin; and it fits in admirably with our up-to-date optimistic, social religion, which allies each and every one of us with the Creative force of the world and places the larger responsibility for the good or evil outcome of affairs upon our own individual and collective efforts. It points out to us so neatly, too, that that place wherever any one happens to emerge on the sea of life is his natural vantage-ground for effort, so that he need lose no time in seeking where to make a start. And if he be in any doubt as to what to do next, I think the story teaches a simple and systematic mode of procedure which is bound "to win out:" The nearest duty that presents itself; the nearest soul who needs a word of comfort or of friendly interest-these should claim one's first consideration. Clear up and set in order the place in which you chance to find yourself; bring in the light; fill it with the creations of your handiwork; clothe it with the beauty of your loving idealism.

We of this company, of course, for one reason or another, all find ourselves allied to pharmacy-some as students and adepts in the science, who are designated as the "professional" members, but the larger part allied simply by family ties or by some other result of fortune. These latter are called the "non-professional" members.

Now it seems, that whereas the professional members of this Women's Section feel keenly their responsibility to the Association, and know what they want to do and have made plans how to do it, and see the very great advantage of all pulling together, according to the old adage, "In union is strength," the non-professional members are inclined to so discredit their own influence in shaping the affairs of pharmacy that it is difficult to secure from them the full cooperation which is necessary for any success of the plans proposed, especially of the educational program which was arranged last year for reaching high school girls and other young women of the country through women's clubs, etc.

Your kind and considerate president, Miss Bagley, therefore, in inviting me (as a courtesy to our New York College of Pharmacy, I take it) to write a paper for this Section, suggested that "perhaps I could refer to this subject and point out definitely where your membership could accomplish definite results."

I assure you I was truly grateful for the suggestion, because it is not an easy matter to. find a topic for a paper, and considerably more difficult to write one to be read before a company with whose tastes and methods of procedure one is entirely unacquainted. Since this. creation story has furnished the rule for my own guidance for many a year, you can understand that I felt bound to agree cordially to do whatever our guests proposed as most agreeable to them. without regard to my own feeling that I was little fitted for the task.

Therefore, from as non-professional a standpoint as any of you can take, I have read over 
the educational program of last year, and find it so admirable in every respect, that I feel sure if it be carried out just as it stands it will bring the desired results.

The publicity work, I believe, is very properly put under the care of the Press Committee, as was planned. And, while that work, in the nature of the case, must be left to a few members only, mostly "professional," the work to be carried on by the Outlook Committee can be put through almost entirely by "non-professionals" as can that described in the third clause of the program.

While, as I said, this program looks to me so admirably planned that it hardly needs revision or suggestions of a more definite character, there is in the second clause, relating to reaching girls with a message about the opportunities in pharmacy for women, a point where various plans might be offered for consideration as to how one might most agreeably and effectively get the attention of fellow club members. A plan like this has occurred to me as feasible, which I present, not because I think it highly original, but hoping that it may provoke discussion, or at least a determination in your minds to think up something a great deal better.

Suppose a member of this Section, presumably a druggist's wife, who is also a member of one of the various women's study clubs, should request that, on the day she is appointed to entertain the club, the topic of discussion should be "Pharmacy as a Profession for Women." Then let her call to her assistance a professional member of this Section or of the local Women's Auxiliary, who is a ready talker and can set forth in an entertaining way the merits of the subject. Let her invite also a bevy of girls from her husband's stor and other drug stores in the vicinity to come in in time to assist her in the serving of the refreshments and in any other entertainment which might enhance in the minds of the guests the attractions of pharmacy. Very possibly the girls from the drug stores might devise the entertainment themselves. At the same time just the introduction of these girls to her guests along with her own daughters, if she be so fortunate as to possess grown daughters, would help greatly towards establishing those desirable social relations, the value of which Mrs. Emma Gray Wallace has so admirably set forth in her paper on "Securing Prestige for Women Pharmacists." (Pharm. Era, 51, 177, 1918.)

The pleasant impression left with the guests by a novel adventure of this kind would remain for a long time and reach an ever widening circle, especially if the experiment were repeated occasionally so that the subject should not pass out of mind. I believe that if the non-professional members would interest themselves in this direction, they could do a wonderftl work, as your president has put it, for pharmacy and indirectly for the A. Ph. A.

So much for the educational program.

If the "non-professional" could get it well established in her mind that she has a mission in life to perform, as undoubtedly every human being has, she would be able to help in many other ways through such an association as this in clearing up and setting chaotic places attached to pharmacy in order.

How often have I wished, as I looked out from my little corner in the library, that there wera some local associations of women interested in the work of the College as the men's association is. There are questions just of good housekeeping which I think could and would be settled much more efficiently by women than by men-naturally so. Anyone who has worked through women's associations for other colleges knows this to be true.

Also, there is always the question arising, you know, about what is going to be done for these girls, to make their lives worth while to themselves and others, after they have cnce been induced to enter pharmacy. This is undoubtedly of not so much concern in the co-cducational universities of the West, where surroundings will be much the same for the young wcmen of the pharmacy course as for those of the academic courses; but in the separate schools, and in the Fost where co-education has not taken very deep root, a good active women's association is reeced to furnish the girls, on occasions, with a little taste of sccial life which they do not have to engineet and pay for themselves, and also to provide the proper supervision of their rest and study rooms so that they shall retain or acquire, those characteristics of cleanliness, neatness, scrvice, etc., which are supposed to be innate in women, and which recommend them especially to the pharmacy profession. My imagination has often conjured up a conmittee of women coming to the College at regular intervals-say cnce a montt-to serve tea informally to the girls and chat with them or bring an intcresting guest to talk to the $\mathrm{m}$ for a $\mathrm{fcw}$ minutes after lectures are over in the alternoon. 
I sometimes dream, too, of pharmacy's coming to the rescue of society with remedies for the social ills as it does with medicaments for the bodily ailments of mankind.

What an opportunity it has for getting together all elements of society! Think of all the nationalities in a big city like this which it unites in a common fellowship! What a convenient place is a drug store to start in with Americanization and the realization of democratic idealssubjects forever on the tongue, but rarely, if ever, in evidence!

If I had time, I should like to enlarge upon this topic, of how the wives of pharmacists, if their husbands were willing, could help to establish a unit of true democracy in every drug store of the land, and lead the world in this respect.

Enough has been said, however, to show that no one is justified in sitting down and being a "slacker," now that peace to the world is in sight, more than during the Great War. Women are needed everywhere for the recreation of society; and each one will render the quickest and most efficient service by starting in wherever she finds herself-that means for us, with pharmacy.

If we need anything to fortify our spirits and give us cheer and endurance in confronting the prejudice and chaos and darkness and disorder that are still rife in the world, we would do well to keep steadily in mind, that to be a creator, as illustrated in the Old Story, we must simply stand fast in the place where we have emerged by choice or chance, clean it up, set it in order, shut out the darkness by bringing in the light, and make it as beautiful as we can.

Following this rule, if we never find time for resting and seeing that all is very good, we shall, at least, find that joy and satisfaction expressed so nobly by Robert Browning:

"Rejoice we are allied

To that which doth provide

And not partake, effect and not receive!

A spark disturbs our clod;

Nearer we hold of God

Who gives, than of His tribes that take, I must believe."

"Then, welcome each rebuff

That turns earth's smoothness rough,

Fach sting that bids nor sit nor stand but go:

Be our joys three-parts pain:

Strive, and hold cheap the strain;

I.earn, nor account the pang; dare, never grudge the throe!"

\section{THE NEW BY-LAWS.}

The Section by vote approved of the By-Laws presented at the last annual meeting and ordered that they be submitted to the Council of the American Pharmaceutical Association for approval. (See pp. 1093-1095, December issue Journal A. Ph. A., I919.)

The Women's Section of the American Pharmaceutical Association was then adjourned.

FX-PRESIDENT FREDERICK J. WULLING OF THE A. PH. A. MAY SUCCEED DR. MARION L. BURTON. AS PRESIDENT OF THE UNIVERSITY OF MINNESOTA.

Word has come, as we go to press, that Dean Frederick J. Wulling, of the Pharmacy Department, University of Minnesota, has been mentioned as a leading possibility for President of the University of Minnesota. President Marion L. Burton goes to Michigan, and thereby the vacancy is created. The Board of Regents will convene January 15 , but a referendum vote has been taken by the faculties, however, not officially announced.

Dean Wulling is a capable administrator and knows educational problems in Minnesota; he is the senior dean of the University, having organized the College of Pharmacy in 1892. He was president of the American Pharmaceutical Association, 1916-I917. Concurrent news conveys the information that Professor Wulling has been offered the presidency of a chëmical manufacturing company and the University does not contemplate losing his services if he can be induced to remain in Minnesota. 